\title{
The Role of Port Authority in Port Governance and Port Community System Implementation
}

\author{
Edvard Tijan $^{1, *\left(\mathbb{D}, \text { Marija Jović }^{1}, \text { Ana Panjako }^{2} \text { and Dražen Žgaljić }\right.}{ }^{1}$ \\ 1 Faculty of Maritime Studies, University of Rijeka, 51000 Rijeka, Croatia; jovic@pfri.hr (M.J.); \\ zgaljic@pfri.hr (D.Ž.) \\ 2 Department of Management, Ca' Foscari University of Venice, 30123 Venice, Italy; ana.panjako@unive.it \\ * Correspondence: etijan@pfri.hr; Tel.: +385-922828964
}

Citation: Tijan, E.; Jović, M.; Panjako,

A.; Žgaljić, D. The Role of Port

Authority in Port Governance and

Port Community System

Implementation. Sustainability 2021,

13, 2795. https://doi.org/10.3390/ su13052795

Academic Editors: Vítor Caldeirinha, J. Augusto Felício and Ademar Dutra

Received: 9 February 2021

Accepted: 28 February 2021

Published: 5 March 2021

Publisher's Note: MDPI stays neutral with regard to jurisdictional claims in published maps and institutional affiliations.

Copyright: (C) 2021 by the authors. Licensee MDPI, Basel, Switzerland. This article is an open access article distributed under the terms and conditions of the Creative Commons Attribution (CC BY) license (https:// creativecommons.org/licenses/by/ $4.0 /)$.
Abstract: This paper researches the role of the port authorities in port governance, and the role of the port authorities in Port Community System implementation. The authors provide the theoretical frameworks of seaports, port authorities, port governance, and Port Community Systems. The literature review was carried out using the Web of Science database and additional relevant sources. The authors concluded that although different port governance models exist (regarding the type of port authority), there is no evidence as to which governance model is universally preferable, as it is specific to each seaport. In addition, the research has shown that port authorities play a very important role in the implementation of a Port Community System, increasing the sustainability of seaport operations. Its implementation enables the port authorities to evolve into real digital hubs and neutral data managers, which ultimately leads to the optimization of seaport processes and more efficient use of transport infrastructure.

Keywords: seaports; port authorities; port governance; port community systems; governance models; sustainability

\section{Introduction}

Seaports, as important nodes in maritime transport, have a significant influence on the economic, social, and environmental development of countries [1] on a local, regional, and national level [2]. Nowadays, sustainability issues are becoming a critical component of maritime logistics [3]. In order to achieve sustainable business, governments (or other types of decision makers) implement port governance structures with clear policy goals [4]. Port governance refers to the interactions between the public and private sectors that influence port organization at various levels, from local to global [5]. It is a complex issue that is inseparable, in different spatial and temporal combinations, from the different stages of history, cultures and geography, and from the different forms of political, economic and administrative organization [6]. Extensive seaport reforms have challenged the conventional models of seaport organization in recent decades [7]. The transformation of the port governance models, including developments such as devolution and regionalization policies, has expanded the autonomy and responsibility of the port authority, giving it a broader role outside the port itself [8]. Port governance has attracted significant attention from scholars, port authorities, policy and decision-makers in the maritime sector over the past three decades, and port governance itself has become an important academic and practical concept in the port sector [9].

Port authorities have traditionally been responsible for the development and improvement of the port area [10] related to port operations, ranging from infrastructure development and maintenance to the marketing and management of port facilities [11]. Acting as a port managing body, port authority takes over public, commercial and economic roles [12]. Several objectives of the general interest of society are followed by the port 
authorities, such as: promoting trade and industry, ensuring long-term sustainable port operation, improving maritime and hinterland connectivity, etc. [13]. Port authorities, as port governance bodies, have been proactive in developing port information systems through the availability and distribution of information technologies, improvement of interaction and exchange information between stakeholders, such as customs, freight forwarders and carriers [11]. In the last decade, new developments in port strategies have emerged around the world: port authorities are changing their nature and function, increasingly taking an active role in the management of logistics systems and sometimes adopting management and entrepreneurial behaviors [14].

Numerous ports are developing and implementing the Port Community Systems (PCS). The introduction of a PCS is identified as one of the key elements facilitating seaport development [15]. Acting as a digital platform, a PCS facilitates the intelligent and protected exchange of information between public and private port users in seaport communities, affecting the sustainable business [16]. It is an effective, real-time, flexible, and complex information system which enables improved efficiency at all stages of the cargo process in the unloading and loading of ships, customs clearance, etc. inside and outside the seaport terminal [17]. The higher the level of collaboration and integration between the port and supply chain stakeholders, the greater the sustainability of both the overall supply chain and the port [18]. Port stakeholders often have individual goals, which can decrease the willingness of certain members of the port community to embrace the PCS. Nonetheless, many seaports like the North Sea ports of Rotterdam, Amsterdam, Antwerp, Zeebrugge, Wilhelmshaven, Bremerhaven, Hamburg, and others have adopted the PCS. These independent PCSs also share and exchange common global shipping data among each other as well as with governmental authorities, i.e., local port authorities [19].

The port authority plays a crucial role in implementing the PCS, considering that in most of the countries it is responsible for coordinating private companies operating in the port area [20].

A lack of research and scientific papers offering a comprehensive overview of the role of port authorities in port governance and the role of port authorities in PCS implementation is particularly pronounced. To overcome this research gap, the authors conducted a literature review on this topic. The goals of this paper are to research the role of the port authority in governing and managing the seaport and the role of the port authority (as the governing body of the port) in the implementation of a PCS. The research problem stems from often outdated execution and monitoring of business processes in seaports. This paper presents a comprehensive review of existing literature, providing a better understanding of the role of port authorities in port governance, the role of port authorities in PCS implementation, and the impact of PCS implementation on sustainability in seaports.

\section{Theoretical Framework}

In this section, the authors provide a review of relevant literature regarding the seaports, port governance, port authorities and PCS.

\subsection{Seaports, Port Governance and Port Authorities}

Seaports are a way of joining the global economic system and play an important role in the growth of trade and the global economy [21]. They are often described as economic entities providing a service between different modes of transport or as facilities through which cargo passes, making an important part of the supply chain and logistics [22]. Owing to their size and complexity, modern seaports cannot be viewed as a single entity. In this respect, as an important part of the transport system, the seaport includes strong cooperation between various stakeholders, such as port authorities, shipping companies, freight brokers, etc. [23].

Governance is a term used for the adoption and implementation of laws regulating behavior and property rights. Adjusting policies and organizational priorities to comply with the contextual economic climate is the scope of governance reform [24]. Port gov- 
ernance is characterized by the laws and regulations imposed by the government on a seaport, and it can be regarded as the corporate governance of the seaport in which the port organization has a fiduciary duty to serve the corporation's ultimate objectives and to serve the shareholders' interests [9].

Port authorities are institutions of a hybrid nature that incorporate elements of both public and private law, regardless of the ownership and management traditions to which they belong [25]. This hybrid nature makes port authorities ideally prepared to face the various challenges placed on the seaport by both market forces and society [12]. In general, the port authority, also known as port management or port administration, is the administrative body of the port [26]. There are many definitions of a port authority such as "the official organization that controls and manages the activities in a port" [27], "land manager with responsibility for a safe, sustainable and competitive development of the port" [28], "state, municipal, public, or private body, which is largely responsible for the tasks of construction, administration and sometimes the operation of port facilities and, in certain circumstances, for security" [26]. In most countries, the port authority is a public or semi-public body responsible for managing and improving the port area through the construction and maintenance of infrastructure, the leasing or concessionary provision of this infrastructure to private companies, and the growth and competitiveness of the port cluster. In a basic context, most port authorities function according to the 'landlord' model, which will be elaborated in the fourth section [29].

Port authorities can be established at all levels of government: national, regional, provincial, or local. The most prevalent form is the local level of government, which means it manages only one port area [26] through its power position and interactions with landlord, regulatory, and community manager functions [30]. The power balance with government is a major factor affecting the legal and regulatory structure, the financial capacity, and the space for a pro-active management culture at the port authority corporate level [25]. Most port authorities, regardless of whether the level of government is national (e.g., Cyprus), regional (e.g., Belgium and the Netherlands) or local (e.g., Korea), have retained at least control over, if not ownership of, the port infrastructure. One exception to this is the case of Taiwan, as most port operations remain state-run in the hands of the port authority [31].

In 2014, PIANC (the World Association for Waterborne Transport Infrastructure) published a Guideline for Port Authorities "Sustainable Ports" which aims to increase the awareness about sustainability issues in ports (such as land use planning, modalities and connectivity, air quality, etc.) and help the port authorities to better face the challenge of becoming sustainable ports with many practical solutions [32]. For example, the Port of Rotterdam Authority is aware of the importance of sustainable business and therefore aims to enhance the port's competitive position as a logistics hub, but at the same time leads the transition to sustainable energy and encourages the digitalization of business processes in order to make the port, and the supply chain, more efficient [33].

\subsection{Port Community System}

PCSs are complex systems for concentrating, centralizing, serving and optimizing business processes within port communities [34] promoting faster and safer data exchange among private and public organizations, with the main goal of improving the seaports' competitiveness [35]. PCSs are defined as centralized port information and data hubs that integrate and distribute data from different sources [36]. The PCS is a system that centralizes the vessels' information and the goods they transport so that the stakeholders can better control and coordinate the movements of goods [37]. The main goals when developing a PCS are, most of all, increasing data quality, paperwork reduction, facilitating data connection between various stakeholders, improving and supporting operations across the entire transport and logistics chain [38]. While both port performance and services provided to stakeholders can be increased by the implementation of the PCS, 
Saragiotis [39] argues that the effect of the implementation of the PCS is higher for the port authority than for the stakeholders.

PCS functions have been divided by Keceli (2011) into three main categories: port management functions (documents provided to port authorities or terminal operators), customs functions (documents needed for customs clearance) and online platforms for electronic commerce between port users [40]. The concept of enhancing collaboration within the port cluster is widespread in the various PCSs, and also included the following elements: the electronic means of communication between the stakeholders in the cluster, the basis for a collaborative working environment, online access to port-related information and the reuse of data and information [41].

Nabais et al. (2018) [42] categorized the PCS development as follows. At the beginning, the PCS included the notification of arrival and departure of ships and cargo for reporting. In a second phase, the PCS included customs and inspection services. In a third phase, consolidation and specialization of procedures occurs, leading to the implementation of automatic processes, in particular automatic billing, with a significant reduction (in some cases elimination) of paperwork at the seaport. The fourth phase is associated with regionalization, with the expansion of the seaport towards the hinterland, including information about maritime supply chains that cross the seaport (information related to road and train operators, dry ports, maritime carriers) making it possible for all actors to access relevant data [42].

\section{Methodology}

To provide a better understanding of the link between port authorities and port governance and the link between the port authorities, as the governing body of the port, and PCS, a comprehensive literature review has been conducted. In total, 73 sources have been identified as relevant for this research. Initially, the search was carried out using the Web of Science database as it represents the world's leading scientific citation search and analytical information platform [43]. We have focused on the following keywords:

- port governance;

- port authority AND port governance

- $\quad$ Port Community System;

- port authority AND Port Community System.

In the Web of Science database, the following limitations were used: TOPIC or TITLE (formal criteria). A search was performed in order to determine whether the publications contained at least one of the search terms in the title, abstract, or the entire manuscript. Articles that were not written in English language were excluded, in order to avoid tentative regional overrepresentation of research in the formal analysis [44]. Table 1 shows the number of hits after applying the reduction criteria for each search term found in the Web of Science database, and number of sources after screening manually.

Table 1. The number of hits after applying the reduction criteria for each search term found in different databases and number of sources after screening manually.

\begin{tabular}{ccc}
\hline Keyword & $\begin{array}{c}\text { Articles after Applying } \\
\text { Formal Criteria }\end{array}$ & Articles after Screening Manually \\
\hline port governance & 112 & 12 \\
port authority AND & 37 & 3 \\
port governance & 48 & 16 \\
Port Community System & 13 & 3 \\
Port Community System & & \\
AND port authority & &
\end{tabular}

The research methodology has been partially adapted from [44]. Figure 1 shows the methodological steps of the research. 


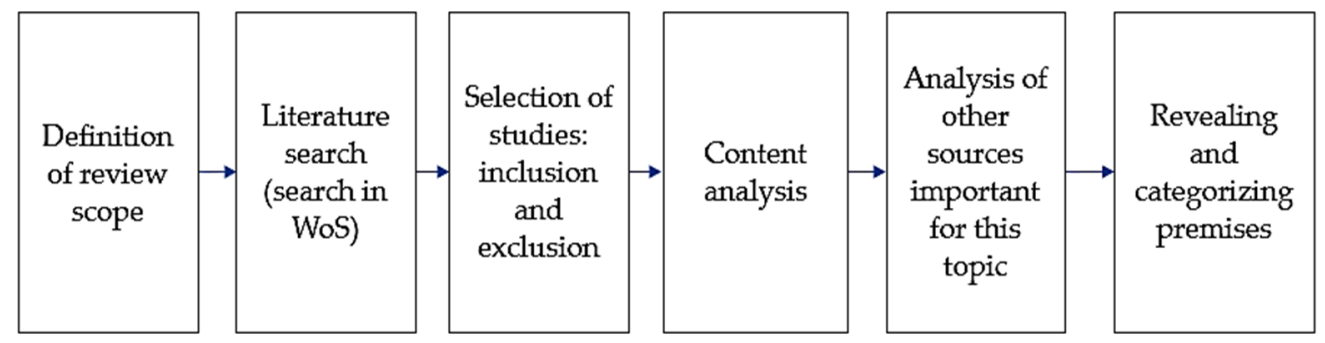

Figure 1. Methodological steps for the research (authors).

Table 2 shows the journals, conferences, books, and the countries of origin, from 2007 to 2021 .

Table 2. The list of journals, conferences, books, and the countries of origin from 2007 to 2021.

\begin{tabular}{|c|c|c|c|c|}
\hline Journal & Country & 2007-2017 & 2018-2019 & 2020-2021 \\
\hline Decision Support Systems & Netherlands & & 1 & \\
\hline Maritime Business Review & $\begin{array}{l}\text { United } \\
\text { Kingdom }\end{array}$ & & 1 & \\
\hline $\begin{array}{l}\text { International Journal of } \\
\text { Engineering Business } \\
\text { Management }\end{array}$ & Croatia & & 1 & \\
\hline Research in Transportation Business \& Management & Netherlands & 4 & 1 & 1 \\
\hline $\begin{array}{c}\text { Promet- } \\
\text { Traffic \&Transportation }\end{array}$ & Croatia & 1 & & \\
\hline $\begin{array}{l}\text { Scientific Journal of } \\
\text { Maritime Research }\end{array}$ & Croatia & 1 & & \\
\hline Estudios de Economia Aplicada & Spain & & 1 & \\
\hline $\begin{array}{l}\text { Transportation Research Record: Journal of the Transportation } \\
\text { Research Board }\end{array}$ & United States & 1 & & \\
\hline $\begin{array}{c}\text { Production Planning \& } \\
\text { Control }\end{array}$ & $\begin{array}{l}\text { United } \\
\text { Kingdom }\end{array}$ & & & 1 \\
\hline $\begin{array}{l}\text { Maritime Policy \& } \\
\text { Management }\end{array}$ & $\begin{array}{l}\text { United } \\
\text { Kingdom }\end{array}$ & 3 & 2 & \\
\hline $\begin{array}{l}\text { Journal of Object } \\
\text { Technology }\end{array}$ & Switzerland & & & 1 \\
\hline IEEE Access & United States & & 1 & \\
\hline Case Studies on Transport Policy & Netherlands & & 1 & \\
\hline Transport Policy & $\begin{array}{l}\text { United } \\
\text { Kingdom }\end{array}$ & & 4 & \\
\hline Procedia Computer Science & Netherlands & 1 & & \\
\hline Transactions on maritime science & Croatia & & & 1 \\
\hline Research in Transportation Economics & $\begin{array}{l}\text { United } \\
\text { Kingdom }\end{array}$ & & & 1 \\
\hline $\begin{array}{l}\text { European Transport } \backslash \\
\text { Trasporti Europei }\end{array}$ & Italy & 1 & & \\
\hline Conference & Country & 2007-2017 & 2018-2019 & 2020-2021 \\
\hline 6th International Conference LDIC 2018, Bremen & Germany & 1 & & \\
\hline $\begin{array}{l}\text { Carpathian Logistics } \\
\text { Conference } 2016\end{array}$ & Poland & 1 & & \\
\hline 8th International Conference on Software Quality Days & Austria & 1 & & \\
\hline $\begin{array}{l}2016 \text { Eighth International Conference on Measuring Technology and } \\
\text { Mechatronics Automation }\end{array}$ & China & 1 & & \\
\hline Book & & 2007-2017 & 2018-2019 & 2020-2021 \\
\hline Reshaping Accounting and Management Control Systems & & 1 & & \\
\hline
\end{tabular}


Afterwards, the authors have also included 17 additional sources important for the topic (including scientific papers, books and PhD theses). After analyzing port governance models and identifying the role of port authorities in PCS implementation, the authors have also included the analysis of several cases in order to demonstrate the importance of port authorities in PCS implementation, such as the Italian "Tuscan Port Community System", the Jamaican PCS, the Polish "Polski Port Community System", Port of Rotterdam, Netherlands, the Port Authority of Valencia, Spain, the Port of Los Angeles, California, the Port Authority of Nagoya, Japan, the Port Authority of the Western Ligurian Sea, Italy, etc.

\section{Port Governance Models}

Port governance structures are implemented by governments or other applicable decision makers with clear policy goals in mind, such as optimizing traffic capacity, maximizing profitability, etc. [4]. In a comprehensive analysis of the port industry 'Port Economics, Management and Policy' (2020), it is stated that the close cooperation between the responsible government department (such as ministry or other relevant policy-actors) and the port authority (which is responsible for the management and operation of the port), is important for the successful governance of a port and/or a port system [45].

Under the influence of external environmental factors, decisions regarding the port governance model can be taken by many stakeholders [8]. At the very start, improvements in governance models may be attributed to changes in the sector, the setting of new targets, etc., but over time, the reasons behind governance reforms are evolving (for example, conventional ports facing physical constraints requiring the creation of new facilities) [46] The nature of port authority, its main roles and relationship with port operators has been one of the main elements of port governance [8].

Four models of port governance have been classified by the World Bank (2001) as shown in the Table 3 ([47]): the public service port, the private port, the tool port (a hybrid model where private sector operators carry out some of the operations but under the direction of public sector managers) and the landlord port (the public sector maintains control, while the terminal management and activities are leased to private sector operators) [48].

Table 3. Basic port management models.

\begin{tabular}{ccccc}
\hline Type & Infrastructure & Superstructure & Port Labor & Other Functions \\
\hline Public service port & Public & Public & Public & Majority private \\
Tool port & Public & Public & Private & Public/private \\
Landlord port & Public & Private & Private & Public/private \\
Private & private & Private & Private & Majority public \\
\hline
\end{tabular}

Ago et al. (2016) suggest that neither of the governance models is more efficient than the other [47]. Except for the public service port model, private firms participate in port operation with varying degrees of involvement. In that case, concession contracts play a key role as a port governance tool [49].

The landlord port model has become the most prevalent and dominant model of port governance, through which a public port authority operates as both a landlord and a regulatory entity, while port operations are conducted by private companies. There are a few forms of the landlord model, based on the extent of decentralization and autonomy of the port authority involved, the cultural disposition of the country considered, or the level of involvement of the landlord in the promotion and enhancement of port activities [31]. Acting as landlords, port authorities are managing bodies in charge of the port area and infrastructure as well as its development [12] including the economic exploitation, the long-term development, etc. [26]. With regard to the strategic importance of land, because of its direct and indirect impact on the regional and sometimes national economy and public health, its inherent value and potential scarcity, port property is hardly sold directly to private parties [26]. According to the analysis of the PCS in a landlord port model by Di 
Vaio and Varriale (2017), the PCS becomes the primary communication mechanism between the port users [35], which is particularly important for the second part of this research.

The World Bank has established a World Bank Port Reform Tool Kit for developing countries in the quest for a perfect model, which focuses on the role (landlord, tool, service or private) and activities of port authorities as a core topic of port governance, but does not provide any evidence as to what governance models lead to better performance results or how ports themselves can respond to a government-imposed governance reform [24].

Port authorities should play a key role in improving the digital transformation of the transport and supply chain, operating as connectors amongst all involved stakeholders in port, seaside and port hinterland [50]. A new management model, the "community manager" model, has been developed in view of recent socio-economic changes and global strategic challenges, which means that port authorities invest into port hinterland ICT network, manage information system on behalf of entire port community etc. [51]. Port authorities are limited to supporting facilities that are beneficial to a broader port community under such an organizational model, like the waste management or the supply of electricity to ships docked at the port [51]. Public stakeholders and, in most cases, port management often provide technological and nautical facilities. Even so, privatization has led to the loss of access by port authorities to essential information that affects their ability to achieve some business needs [51].

\section{Port Authority and PCS Implementation}

Port authorities can develop into real digital hubs and neutral data managers at the service of the transport and logistic chain. By gathering and exchanging real-time information among different parties in the process, logistics processes can be optimized, and transport infrastructure can be used in a more efficient way [12]. Port Authority holds an important role as initiator and creator of the port development strategy and coordination of the entire Port Community [42]. As the port authority is responsible for safe, sustainable and competitive development of the seaport, it may represent the most important factor of PCS implementation [52]. The implementation of the PCS can provide benefits for the port authority because port authorities will be able to more easily coordinate port activities, monitor the activities of port operators and control port operations [53]. In this way, port authorities will be able to make better-informed decisions that will encourage sustainable seaport operations.

Value-added services of PCS are considered as co-innovations, namely a new form of innovation where several stakeholders participate together to create new knowledge, insight and opportunities for cooperation [54], which further improves sustainable business. The role of such initiatives becomes vital particularly for competing ports located in close geographical markets [54]. In this respect, the following case indicates the importance of cooperation between stakeholders. The Italian "Tuscan Port Community System" (TPCS) is the Port Community System of the Port Authority of Northern Tyrrhenian Sea (Ports of Livorno, Piombino, Capraia, Portoferraio, Rio Marina and Cavo). The TPCS is a web-services based platform with multilevel access control and data recovery facilities [55], with the aim to digitalize and simplify the complex logistics flows. The TPCS Technical Commission, established in 2016, is coordinated by the Port Authority of Northern Tyrrhenian Sea, and is composed by representatives of Terminal and Category Association. The TPCS Technical Commission has intervened on the system to improve the service quality and design new functions compliant with both the recent legislative provisions and the users' needs [56]. TPCS processes a huge amount of information allowing a reduction in costs and streamlining bureaucratic procedures [55], affecting the economic aspect of seaport sustainability.

The Jamaican PCS is developed by the Port Authority of Jamaica in partnership with the Customs Agency, along with support of the Shipping Association of Jamaica [57]. The Jamaican PCS integrates private-sector companies with public-sector entities, allowing for improved efficiency and effectiveness in trade and logistics-related activities, affecting the 
sustainability of business processes and overall sustainability (e.g., reducing the need for people to congregate at the ports, thereby limiting the need for physical interaction, which is critical in the fight against the novel coronavirus) [57].

The following case indicates the importance of cooperation of different port authorities in the implementation of a PCS in order to achieve sustainable business. The Polish PCS, "Polski Port Community System" is owned by Port of Gdańsk Authority S.A., Szczecin and Świnoujście Seaports Authority S.A. and PGZ System Sp. z o.o. in Radom, and the Port of Gdynia Authority S.A., Poland is expected to join. Each Port Authority will be the holder of equal percentage of the shares in the Polski PCS [58]. The basic aim of the Polski PCS system is to optimize the management of transport processes by collecting, combining and processing traffic data and other logistics-related data in one place, and to ultimately enable sustainable business throughout the supply chain [59].

Chandra and van Hillegersberg (2017) [60] have conducted the case study of Port of Rotterdam, Netherlands, in which the importance of port authorities in PCS implementation has been researched (Figure 2).

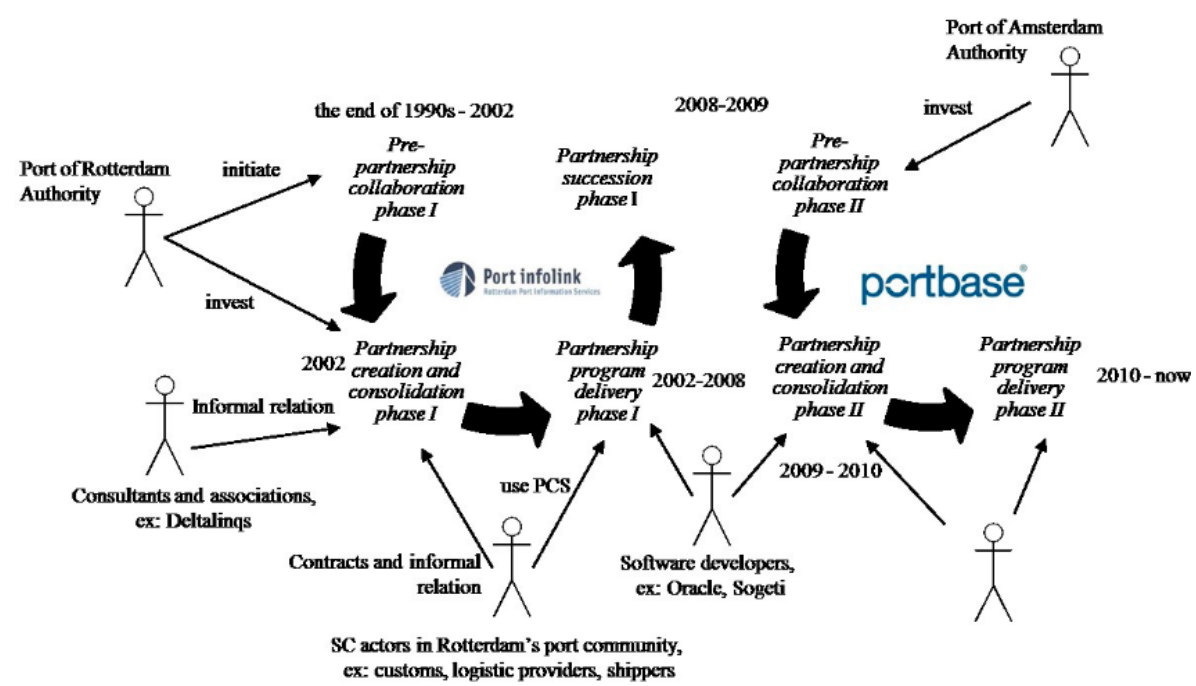

Figure 2. The governance lifecycle of Rotterdam's port community and the involved actors.

According to the study, due to dissatisfaction with the Port of Rotterdam information system, Port Infolink B.V. was established in 2002 as a separated governance entity. The pre-partnership cooperation phase was initiated by the Port of Rotterdam Authority and began by identifying the most critical problem that hinders the efficient flow of goods through the seaport, which were the import processes. The Port Authority was the sole owner of Port Infolink, which means that it bore the initial investment in the development of the information system, as seen in Figure 2. This project involved other stakeholders in the partnership program delivery phase (e.g., Customs, as one of the lead user). In early 2009, the next governance life cycle was marked by the merger of Port Infolink in Rotterdam and PortNET in Amsterdam, which provided the Ports of Rotterdam and Amsterdam with a joint PCS [60]. In this case, it is visible that Port of Rotterdam Authority has played an important role from the beginning, first as an initiator, and then as the initial investor.

The Port Authority of Valencia, Spain, is equipped with a series of tools intended to increase the competitiveness of port community companies and to improve sustainable business, and one of them is the technological platform ValenciaportPCS [61]. Through ValenciaportPCS, the Port Authority of Valencia provides e-commerce solutions that facilitate the passage of goods through the ports of Valencia, Sagunto, and Gandía, adding clearly perceptible value for customers and port users [61].

The Port of Los Angeles, USA and the Port Authority of Nagoya, Japan inked a Memorandum of Understanding to boost cooperation and exchange information on projects focused on operational efficiency and environmental sustainability. Through the Memoran- 
dum of Understanding, the port of Los Angeles will develop its port community system as the port optimizer and the digital data platform. In this way, cooperation and exchange of information on port community systems will be improved [62].

Furthermore, as supply chains become more integrated, hinterland operations become more pronounced. Port authorities can start up strategy relations with other transport nodes in the hinterland, which are usually aimed at: traffic management, land management, hinterland connections, etc. [63]. Baccelli and Morino (2020) [64] have analyzed the role of port authorities in the promotion of logistics integration between ports and the railway system. The Italian Port Authority of the Western Ligurian Sea (which includes the seaports: Genoa, Prà, Savona and Vado Ligure) and Rete Ferroviaria Italiana railway operator have defined the last elements of the agreement of interoperability between the Railway Circulation Integrated Platform and the Port Community System [64]. The interoperability of these two systems through a structured and organized electronic dialogue will allow a better and more efficient management of documents [64], affecting the sustainable business. It will be possible to have information and documents which are judged important by shipping companies and port terminal operators well in advance, e.g., the position of the train on the railway network [64].

\section{Discussion and Conclusions}

Seaports are providing a major contribution in the growth of global trade as well as major impact in national economies. Seaports involve a broad range of stakeholders, where a strong collaboration and communication is inevitable. Seaports also play an important role in sustainable development, where the implementation of port activities, operations and management practices should be environmentally friendly.

The body that is responsible for the implementation of laws, port development and port improvement is usually the port authority. In other words, port authorities are usually responsible for growth and competitiveness of a port cluster by governing the port area, managing port activities, handling hinterland connections and collecting real estate revenue. Port authorities also have extensive administrative powers to implement policies, laws and regulations. In recent times, the focus is put on the sustainable port development, raising awareness of resolving port sustainability issues (such as air quality, land use planning, modalities and connectivity) that affect port authorities to make some fundamental changes in the process of transforming the ports that they govern into sustainable ports. Various port governance models regarding the type of port authority exist and there is no evidence as to which governance model results in better performance outcomes, as it is specific to each seaport.

Port governance models depend on external environmental impacts as well on the nature of port authority, such as levels of autonomy and centralization, its key functions and collaboration with the port operators. Depending on the influence of beforementioned factors, the World Bank classified four port governance models: the public service port, the private port, the tool port and the landlord port. Each model is unique, and there is no given evidence on which model performs better in terms of productivity and financial outcomes. Recent digital transformation accompanying socio-economic changes and global strategic challenges have triggered a new management model known as community manager model. With such a function, the role of the port authority is manifested in ensuring mutual coordination and the efficiency of different port service providers, investing into port hinterland network, managing information system on behalf of entire port community, etc.

To remain competitive, numerous seaports have begun to implement Port Community Systems, where all port information is centralized and data exchange between port stakeholder is safer and faster. Desired outcomes from the implementation of PCS, apart from increasing the quality of data are minimizing paperwork, supporting data connections between different stakeholders, enhancing and facilitating activities across the entire transport and logistics chain to stakeholders, etc. Port authorities act as initiators and creators of the sustainable port development strategy on behalf of the whole port community. By 
developing and implementing a PCS, port authorities are becoming real digital hubs, where available data is gathered and exchanged between various stakeholders.

Table 4 shows the case studies elaborated in this paper, with the respective port authorities, countries, port governance models, and characteristics of the PCS implementation.

Table 4. Port authorities, port governance models and PCS implementation.

\begin{tabular}{|c|c|c|c|}
\hline Port Authority & Country & Port Governance Model & PCS Implementation \\
\hline $\begin{array}{l}\text { The Port Authority of } \\
\text { Northern Tyrrhenian } \\
\text { Sea (Ports of Livorno, } \\
\text { Piombino, Capraia, } \\
\text { Portoferraio, Rio } \\
\text { Marina and Cavo). }\end{array}$ & Italy & Landlord [65] & $\begin{array}{l}\text { "Tuscan Port } \\
\text { Community System" } \\
\text { aims to digitalize and } \\
\text { simplify the complex } \\
\text { logistics flows }\end{array}$ \\
\hline $\begin{array}{c}\text { Port Authority } \\
\text { of Jamaica }\end{array}$ & Jamaica & Landlord [66] & $\begin{array}{l}\text { PCS aims to integrate } \\
\text { private-sector } \\
\text { companies with } \\
\text { public-sector entities, } \\
\text { to improve efficiency } \\
\text { and effectiveness in } \\
\text { trade and } \\
\text { logistics-related } \\
\text { activities }\end{array}$ \\
\hline $\begin{array}{c}\text { Port of Gdańsk } \\
\text { Authority S.A.; } \\
\text { Szczecin and } \\
\text { Świnoujście Seaports } \\
\text { Authority S.A.; Port } \\
\text { of Gdynia Authority } \\
\text { S.A. }\end{array}$ & Poland & $\begin{array}{c}\text { Landlord [67]; Landlord } \\
\text { [68], } \\
\text { Public-service [69] }\end{array}$ & $\begin{array}{c}\text { Polski Port } \\
\text { Community System } \\
\text { aims to optimize the } \\
\text { management of } \\
\text { transport processes; } \\
\text { to enable sustainable } \\
\text { business throughout } \\
\text { the supply chain }\end{array}$ \\
\hline Port of Rotterdam & Netherlands & Landlord [70] & $\begin{array}{l}\text { Portbase aims to } \\
\text { make supply chains } \\
\text { that run through the } \\
\text { Netherlands stronger } \\
\text { and smarter }\end{array}$ \\
\hline $\begin{array}{l}\text { Port Authority } \\
\text { of Valencia }\end{array}$ & Spain & Landlord [71,72] & $\begin{array}{l}\text { ValenciaportPCS aims } \\
\text { to facilitate the } \\
\text { passage of goods } \\
\text { through the ports, } \\
\text { adding a clearly } \\
\text { perceptible value for } \\
\text { customers and port } \\
\text { users }\end{array}$ \\
\hline $\begin{array}{c}\text { Port Authority } \\
\text { of Nagoya }\end{array}$ & Japan & Public-service [73] & $\begin{array}{l}\text { Cooperation and } \\
\text { exchange of } \\
\text { information between } \\
\text { different port } \\
\text { community systems }\end{array}$ \\
\hline $\begin{array}{l}\text { The Port Authority of } \\
\text { the Western Ligurian } \\
\text { Sea (Port of Genoa, } \\
\text { Prà, Savona and } \\
\text { Vado Ligure) }\end{array}$ & Italy & Landlord [65] & $\begin{array}{c}\text { Interoperability } \\
\text { between the Railway } \\
\text { Circulation Integrated } \\
\text { Platform and the Port } \\
\text { Community System }\end{array}$ \\
\hline
\end{tabular}

In this paper, the concrete relation between the different types of governance model and the different types of PCS implementation is not visible. For example, the Port of Nagoya may be considered as a public service port, while port of Rotterdam repre- 
sents a landlord port. In all cases, port authorities have played an important role in PCS implementation-as initiators, with the aim to facilitate data exchange, either by focusing on the port itself or on the supply chain. However, the success depends on collaboration between all involved stakeholders.

The Italian "Tuscan PCS", Jamaican PCS and the Polish "Polski PCS" are some of the most prominent examples of the PCS implementation in means of improved collaboration among stakeholders and safer and faster data exchange, affecting the economic, social and environmental aspects of sustainability. By identifying the issues that hinder the efficient flow of goods through the seaport, Port of Rotterdam implemented a PCS by merging the Port Infolink in Rotterdam and PortNET in Amsterdam. Although the implementation of a PCS indeed facilitates the collaboration between all involved stakeholders, it increasingly affects the port authorities themselves. It enables them to organize port activities more efficiently, track port operators' activities and manage port operations more easily.

Since supply chains are becoming more integrated, the port authorities are focused not only on the port community, but also on relations with other transport nodes in the hinterland, through the interoperability of the PCS with other systems such as the Circulation Integrated Platform for the railway system. It will result in facilitating electronic communication and paperwork, also positively affecting business sustainability.

Port authorities play an important role in PCS implementation. However, it is necessary to note that other stakeholders have individual preferences, therefore, various PCS business models may be developed. In the future research, different models of introducing an integrated Port Community System in seaports should be analyzed because it will determine the specific financial model and goals that PCS as a project aspires to. In their future research, the authors will focus towards investigating the role of port authorities in financing and maintaining the PCS.

This paper (when compared to previously published papers dealing with this topic) provides a clearer insight into two research objects: the role of the port authority in governing and managing the seaport, and the role of the port authority in PCS implementation. This research is based on the literature review (which also presents the main limitation of the research), and as such offers an initial overview of the role of port authority in port governance, and the role of port authority in PCS implementation.

Author Contributions: Conceptualization, E.T., A.P., M.J. and D.Ž.; methodology, E.T.; validation, E.T. and D.Ž.; formal analysis, M.J. and A.P.; investigation, E.T., A.P. and M.J.; resources, A.P. and M.J.; writing—original draft preparation, A.P., E.T. and M.J.; writing-review and editing, E.T. and D.Ž.; visualization, M.J. and A.P.; supervision, E.T. and D.Ž.; project administration, E.T.; funding acquisition, E.T., M.J. and D.Ž. All authors have read and agreed to the published version of the manuscript.

Funding: This research received no external funding.

Institutional Review Board Statement: Not applicable.

Informed Consent Statement: Not applicable.

Data Availability Statement: Data sharing not applicable.

Acknowledgments: This work was supported by "DigLogs-Digitalising Logistics Processes" (Interreg V-A Italy-Croatia 2014-2020) project.

Conflicts of Interest: The authors declare no conflict of interest.

\section{References}

1. Hlali, A.; Hammami, S. Seaport Concept and Services Characteristics: Theoretical Test. Open Transp. J. 2017, 11, 120-129. [CrossRef]

2. IPL. Seaport Advantages. Available online: https://www.ipl.org/essay/Sea-Port-Advantages-PKZBQJ3RCED6 (accessed on 10 January 2021).

3. Shin, S.H.; Kwon, O.K.; Ruan, X.; Chhetri, P.; Lee, P.T.W.; Shahparvari, S. Analyzing sustainability literature in maritime studies with text mining. Sustainability 2018, 10, 3522. [CrossRef] 
4. Pallis, A. Chapter 4.1-Port Governance and Reform. 2021. Available online: https://porteconomicsmanagement.org/pemp/ contents/part4/port-reform-and-governance/ (accessed on 25 January 2021).

5. De Martino, M.; Magnott, F.; Morvillo, A. Port governance and value creation in the supply chain: The case of Italian ports. Case Stud. Transp. Policy 2019, 8, 373-382. [CrossRef]

6. Cepal. The Great Challenge for Ports: The Time Has Come to Consider a New Port Governance. 2015. Available online: https:/ / www.cepal.org/en/publications/37858-great-challenge-ports-time-has-come-consider-new-port-governance (accessed on 25 January 2021).

7. Brooks, M.R.; Pallis, A.A. Assessing port governance models: Process and performance components. Marit. Policy Manag. 2008, 35, 411-432. [CrossRef]

8. Caldeirinha, V.R.; Felício, J.A.; da Cunha, S.F.; da Luz, L.M. The nexus between port governance and performance. Marit. Policy Manag. 2018, 45, 877-892. [CrossRef]

9. Zhang, Q.; Zheng, S.; Geerlings, H.; El Makhloufi, A. Port governance revisited: How to govern and for what purpose? Transp. Policy 2019, 77, 46-57. [CrossRef]

10. van der Lugt, L.M. Beyond the Landlord: A Strategic Management Perspective on the Port Authority. Amsterdam Business Research Institute. 2015. Available online: https:/ / research.vu.nl/en/publications/beyond-the-landlord-a-strategic-managementperspective-on-the-por (accessed on 10 January 2021).

11. Rodrigue, J.-P.; Notteboom, T. 6.3-Port Terminals. Available online: https://transportgeography.org/contents/chapter6/portterminals / (accessed on 10 January 2021).

12. European Sea Ports Organisation. Priorities of European Ports for 2019-2024. 2019. Available online: https://www.espo.be/ media/MemorandumESPOFINALDigitalversion.pdf (accessed on 1 October 2020).

13. ESPO Project. Trends in EU Ports Governance. 2016. Available online: https://www.espo.be/media/espopublications/Trends in_EU_ports_gouvernance_2016_FINAL_VERSION.pdf (accessed on 2 February 2021).

14. Cepolina, S.; Ghiara, H. New trends in port strategies. Emerging role for ICT infrastructures. Res. Transp. Bus. Manag. 2013, 8, 195-205. [CrossRef]

15. Torlak, I.; Tijan, E.; Aksentijević, S.; Oblak, R. Analysis of Port Community System Introduction in Croatian Seaports-Case Study Split. Trans. Marit. Sci. 2020, 9, 331-341. [CrossRef]

16. Simoni, M.; Schiavone, F.; Risitano, M.; Leone, D.; Chen, J. Group-Specific Business Process Improvements via a Port Community System: The Case of Rotterdam. Production Planning \& Control. 2020. Available online: https://www.tandfonline.com/doi/ abs/10.1080/09537287.2020.1824029?journalCode=tppc20 (accessed on 26 January 2021).

17. Caldeirinha, V.; Felício, J.A.; Salvador, A.S.; Nabais, J.; Pinho, T. The Impact of Port Community Systems (PCS) Characteristics on Performance. Research in Transportation Economics. 2020. Available online: https:/ /www.sciencedirect.com/science/article/ pii/S073988592030007X (accessed on 18 February 2021).

18. Tijan, E.; Agatić, A.; Jović, M.; Aksentijević, S. Maritime National Single Window-A Prerequisite for Sustainable Seaport Business. Sustainability 2019, 11, 4570. [CrossRef]

19. Maeder, C.; Sohr, K.; Nguempnang, R.W.; Meyer-Larsen, N.; Müller, R. Modeling and Validating Role-Based Authorization Policies for a Port Communication System with UML and OCL. J. Object Technol. 2020, 19. [CrossRef]

20. Nota, G.; Bisogno, M.; Saccomanno, A. A service-oriented approach to modeling and performance analysis of Port Community Systems. Int. J. Eng. Bus. Manag. 2018, 10, 1-17. [CrossRef]

21. Dwarakish, G.S.; Salim, A.M. Review on the Role of Ports in the Development of a Nation. Aquat. Procedia $2015,4,295-301$. [CrossRef]

22. Woo, S.-H.; Pettit, S.J.; Kwak, D.-W.; Beresford, A.K.C. Seaport research: A structured literature review on methodological issues since the 1980s. Transp. Res. Part A 2011, 45, 667-685. [CrossRef]

23. Tijan, E.; Jović, M.; Karanikić, P. Economic and Ecological Aspects of Electronic Transportation Management Systems in Seaports. In Proceedings of the Maritime and Port Logistics Bar Conference, Bar, Montenegro, 1-2 July 2019; Available online: https:/ / www.bib.irb.hr/1003853 (accessed on 28 December 2020).

24. Brooks, M.R.; Pallis, A.A. Port Governance. In Maritime Economics—A Blackwell Companion; Blackwell Publishing: Hoboken, NJ, USA, 2011; pp. 491-516.

25. Verhoeven, P. A review of port authority functions: Towards a renaissance? Marit. Policy Manag. 2010, 37, 247-270. [CrossRef]

26. PPIAF. Alternative Port Management Structures and Ownership Models. Available online: https://ppiaf.org/sites/ppiaf.org/ files/documents/toolkits/Portoolkit/Toolkit/module3/port_functions.html (accessed on 28 December 2020).

27. Cambridge Dictionary. Port Authority. Available online: https://dictionary.cambridge.org/dictionary/english/port-authority (accessed on 1 October 2020).

28. van der Lugt, L.; De Langen, P.W. Port Authority Strategy: Beyond the Landlord a Conceptual Approach. 2018. Available online: https://www.researchgate.net/publication/228814779_PORT_AUTHORITY_STRATEGY_BEYOND_THE_LANDLORD_ A_CONCEPTUAL_APPROACH (accessed on 28 December 2020).

29. Dooms, M.; van der Lugt, L.; de Langen, P.W. International strategies of port authorities: The case of the Port of Rotterdam Authority. Res. Transp. Bus. Manag. 2013, 8, 148-157. [CrossRef]

30. Zhang, Q.; Geerlings, H.; El Makhloufi, A.; Chen, S. Who governs and what is governed in port governance: A review study. Transp. Policy 2018, 64, 51-60. [CrossRef] 
31. Brooks, M.R.; Cullinane, K.P.B.; Pallis, A.A. Revisiting port governance and port reform: A multi-country examination. Res. Transp. Bus. Manag. 2017, 22, 1-10. [CrossRef]

32. PIANC (World Association for Waterborne Transport Infrastructure). Sustainable Ports'A Guide for Port Authorities. 2014 Available online: https:/ / sustainableworldports.org/wp-content/uploads/EnviCom-WG-150-FINAL-VERSION.pdf (accessed on 28 December 2020).

33. Port of Rotterdam Authority. Port of Rotterdam Authority. 2020. Available online: https://www.portofrotterdam.com/en/portof-rotterdam-authority (accessed on 28 December 2020).

34. Tijan, E.; Kos, S.; Ogrizović, D. Disaster recovery and business continuity in port community systems. Sci. J. Marit. Res. 2009, 23, 243-260.

35. Di Vaio, A.; Varriale, L. AIS and Reporting in the Port Community Systems: An Italian Case Study in the Landlord Port Model. In Reshaping Accounting and Management Control Systems; Springer: Berlin/Heidelberg, Germany, 2017; pp. $153-165$.

36. Meyer-Larsen, N.; Müller, R. Enhancing the Cybersecurity of Port Community Systems. In Dynamics in Logistics; Springer: Berlin/Heidelberg, Germany, 2018; pp. 318-323.

37. Sarabia-Jácome, D.; Palau, C.E.; Esteve, M.; Boronat, F. Seaport Data Space for Improving Logistic Maritime Operations. IEEE Access 2019, 8, 4372-4382. [CrossRef]

38. Marek, R. A Qualitative Analysis of Using Swibż System into Creation of Polish Port Community System. 2016. Available online: https:/ / www.confer.cz/clc/2016/2746-a-qualitative-analysis-of-using-swizb-system-into-creation-of-polish-portcommunity-system (accessed on 30 January 2021).

39. Saragiotis, P. Business process management in the port sector: A literature review. Marit. Bus. Rev. 2019, 4, 49-70. [CrossRef]

40. Keceli, Y. A proposed innovation strategy for Turkish port administration policy via information technology. Marit. Policy Manag. Flagsh. J. Int. Shipp. Port Res. 2011, 38, 151-167. [CrossRef]

41. Gustafsson, I. Interaction between Transport, Infrastructure, and Institutional Management, Case Study of a Port Community System. Transp. Res. Rec. J. Transp. Res. Board 2007, 2033, 14-20. [CrossRef]

42. Nabais, J.L.; Batista, J.C.; Ayala Botto, M.; Cordón Lagares, E. Computational Framework for Port Community Systems Towards Synchromodal Freight Networks. Estud. Econ. Appl. 2018, 36, 691-714. [CrossRef]

43. Li, K.; Rollins, J.; Yan, E. Web of Science use in published research and review papers 1997-2017: A selective, dynamic, crossdomain, content-based analysis. Scientometrics 2018, 115, 1-20. [CrossRef] [PubMed]

44. Dreyer, S.; Olivotti, D.; Lebek, B.; Breitner, M.H. Focusing the customer through smart services: A literature review. Electron. Mark. 2019, 29, 55-78. [CrossRef]

45. Notteboom, T.; Pallis, A.; Rodrigue, J.-P. Port Economics, Management and Policy. 2020. Available online: https: / / porteconomicsmanagement.org/?page_id=135 (accessed on 28 December 2020).

46. Laxe, F.G.; Sánchez, R.J.; Garcia-Alonso, L. The Adaptation Process in Port Governance: The Case of the Latin Countries in South America and Europe. J. Shipp. Trade 2016. Available online: https://jshippingandtrade.springeropen.com/articles/10.1186/s410 72-016-0018-y (accessed on 28 December 2020).

47. Ago, T.E.; Yang, H.; Enam, T.D.A. Review of Port Governance in Ghana. In Proceedings of the 2016 Eighth International Conference on Measuring Technology and Mechatronics Automation Icmtma, Macau, China, 11-12 March 2016; pp. $26-31$.

48. Monios, J. Polycentric port governance. Transp. Policy 2019, 83, 26-36. [CrossRef]

49. Munim, Z.H.; Saeed, N.; Larsen, O.I. "Tool port" to "landlord port": A game theory approach to analyse gains from governance model transformation. Marit. Policy Manag. 2018, 46, 43-60. [CrossRef]

50. Safety4sea. ESPO Presents European Ports' Priorities for 2019-2024. 2019. Available online: https://safety4sea.com/espopresents-european-ports-priorities-for-2019-2024/ (accessed on 28 December 2020).

51. Mendes Constante. International Case Studies and Good Practices for Implementing Port Community Systems. 2019. Available online: https:/ / publications.iadb.org/publications/english/document/International_Case_Studies_and_Good_Practices_for_ Implementing_Port_Community_Systems.pdf (accessed on 15 January 2021).

52. Tijan, E.; Agatić, A.; Hlača, B. The Necessity of Port Community System Implementation in the Croatian Seaports. PROMET Traffic Transp. 2012, 24, 305-315. [CrossRef]

53. Carlan, V.; Sys, C.; Vanelslander, T. How port community systems can contribute to port competitiveness: Developing a cost-benefit framework. Res. Transp. Bus. Manag. 2016, 19, 51-64. [CrossRef]

54. Irannezhad, E.; Prato, C.G.; Hickman, M. An intelligent decision support system prototype for hinterland port logistics. Decis. Support Syst. 2020, 130, 113227. [CrossRef]

55. Spagnolo, O.; Marchetti, E.; Coco, A.; Scarpellini, P.; Querci, A.; Fabbrini, F.; Gnesi, S. An Experience on Applying Process Mining Techniques to the Tuscan Port Community System. In Proceedings of the International Conference on Software Quality, Vienna, Austria, 18-21 January 2016; pp. 49-60. Available online: https://link.springer.com/chapter/10.1007/978-3-319-27033-3_4 (accessed on 15 January 2021).

56. Tuscan Port Community System. What Is TPCS, Tuscan Port Community System. 2021. Available online: https://tpcs.tpcs.eu/ login-en.aspx (accessed on 25 January 2021).

57. Jamaica Observer. Port Community System Making Doing Business Easier during COVID Fight. 2020. Available online: https: //jis.gov.jm/features/port-community-system-making-doing-business-easier-during-covid-19/ (accessed on 25 January 2021). 
58. Port of Gdynia Authority S.A. Preparation to PCS at the Port of Gdynia. Available online: https://www.port.gdynia.pl/en/ tender/tenders-archive/589-05-08-2016r-wykonanie-uzupelniajacej-analizy-falowania-dla-poszerzenia-przejscia-pilotowego (accessed on 25 January 2021).

59. Polski PCS. About the Company, Polish PCS. 2021. Available online: https://polskipcs.pl/de/about-company (accessed on 25 January 2021).

60. Chandra, D.R.; van Hillegersberg, J. Governance lifecycles of inter-organizational collaboration: A case study of the Port of Rotterdam. Procedia Comput. Sci. 2017, 121, 656-663. [CrossRef]

61. Port Authority of Valencia. 2021. Available online: https://www.valenciaportpcs.com/en/community/port-authority/ (accessed on 29 January 2021).

62. Safety4sea. Ports of LA and Nagoya to Boost Port Community Systems and Sustainability. 2020. Available online: https: // safety4sea.com/ports-of-la-and-nagoya-to-boost-port-community-systems-and-sustainability/ (accessed on 29 January 2021).

63. Donselaar, P.W. Societal Costs and Benefits of Cooperation between Port Authorities. Marit. Policy Manag. 2010, 37, $271-284$. [CrossRef]

64. Baccelli, O.; Morino, P. The role of port authorities in the promotion of logistics integration between ports and the railway system: The Italian experience. Res. Transp. Bus. Manag. 2020, 35, 100451. [CrossRef]

65. Baccelli, O.; Percoco, M.; Tedeschi, A. Port Authorities as cluster managers: The case of the Ligurian ports. Eur. Transp. Trasp. Eur. 2008. Available online: https:/ / core.ac.uk/download/pdf/41174627.pdf (accessed on 27 February 2021).

66. Pinnock, F.H.; Ajagunna, I.A. The Caribbean Maritime Transportation Sector: Achieving Sustainability through Efficiency. The Caribbean Papers-A Project on Caribbean Economic Governance. 2012. Available online: https://www.files.ethz.ch/isn/1417 22/no.13.pdf (accessed on 27 February 2021).

67. New Deepwater Port Will Transform Gdansk into a Baltic Mega-Hub for Eastern Europe. 2015. Available online: https: / / theloadstar.com/new-deepwater-port-will-transform-gdansk-baltic-mega-hub-eastern-europe/ (accessed on 27 February 2021).

68. Klimek, H.; Michalska-Szajer, A.; Dąbrowski, J. Corporate social responsibility of the Ports of Szczecin and Świnoujście. Sci. J. Marit. Univ. Szczec. 2020, 61, 99-107.

69. Port of Gdynia Authority S.A. General Port Informations. 2021. Available online: https://www.port.gdynia.pl/en/portauthority/general-information (accessed on 27 February 2021).

70. Van Schuylenburg, M. The Port of Rotterdam, Your Intermodal Gateway to Europe. 2019. Available online: https: / / www.google.com/url?sa=t\&rct=j\&q=\&esrc=s\&source=web\&cd=\&ved=2ahUKEwj5gvyg_YHvAhUFtRoKHeW7DAs4 ChAWMAB6BAgDEAM\&url=https\%3A\%2F\%2Fwww.netherlandsworldwide.nl\%2Fbinaries\%2Fen-nederlandwereldwijd \% 2Fdocuments $\% 2$ Fpublications $\% 2 F 2019 \% 2 F 10 \% 2 F 04 \% 2 F$ presentation-port-of-rotterdam $\% 2 F 2 . \% 2 B P r e s e n t a t i o n \% 2 B M . \% 2$ Bvan\%2BSchuylenburg\%2BPort\%2Bof\%2BRotterdam.pdf\&usg=AOvVaw3kO3vwH0-eCBb0wMQzZXXP (accessed on 27 February 2021).

71. Valenciaport. About Us. 2021. Available online: https://www.valenciaport.com/en/port-authority-valencia/about-valenciaport/about-us / (accessed on 27 February 2021).

72. Valenciaport. Concession and Authorisation Tenders. 2021. Available online: https://www.valenciaport.com/en/port-authorityvalencia/concession-authorisation-tenders / (accessed on 27 February 2021).

73. Shinohara, M.; Saika, T. Port governance and cooperation: The case of Japan. Res. Transp. Bus. Manag. 2018, 26, 56-66. [CrossRef] 